Check for updates

London, UK

Cite this as: BMJ 2020;371:m4083 http://dx.doi.org/10.1136/bmj.m4083 Published: 26 October 2020

\section{Why I ... ride a motorcycle}

\section{Anaesthetist Andrew Coe tells Francesca Robinson how riding a motorbike distracts him from work stress}

Francesca Robinson

Andrew Coe is known for avoiding excessive risks at work but in his free time he rides motorcycles-one of the most dangerous ways of travelling by road (per mile travelled, the risk of death for a motorcyclist is at least 57 times higher than that for a car occupant). "Riding a motorcycle is extremely hazardous but it's great fun," he says.

Coe's passion for motorcycles was kindled in childhood; his father and brother rode them and his uncle owned a motorbike shop. He has ridden since he was 17. A pile-up that he experienced aged 21, however, as well as the responsibilities of having a family, deterred him from riding in his middle years.

But, in common with many middle aged men, he became a born again biker in his early fifties. Now aged 61, and currently taking a break in between retiring and returning to work for Hull University Teaching Hospitals NHS Trust, he has more time to enjoy his hobby.

For Coe, there are many reasons to be a biker. "Firstly, for a motorcyclist, a bike is a thing of beauty and skilled design," he says.

Most of all though, it is the experience of riding when every sense is heightened, says Coe. "Even on the quieter roads you don't think about anything but riding the bike," he says. "It is too dangerous a task to let your mind wander. It's a far more demanding skill than driving a car.”

If he drives to work by car, Coe often worries about all manner of stressful work related problems. His rural route can also be frustrating as there are few places to overtake the tractors and lorries that can clog up the rural Lincolnshire roads.

When he is riding his motorbike, slow traffic is no longer a problem. "Overtaking is great fun," Coe says. "The best bit is after you pull out. The bike is now upright and you can 'safely' let all the horses out to play. At this point the bike makes a truly awesome sound.

"When I get to work on my motorcycle I am simply delighted to have survived the trip. Any worries about a lack of intensive care beds, funding cuts, irritating colleagues, or even covid-19 are, by then, fully in perspective," he says.

Coe owns a Triumph Street Triple that he uses for everyday trips and travelling to work when the weather is reasonable. He also owns a Suzuki sports bike which he rides at weekends along the A roads in north Lincolnshire where he lives. With their windy bends and hills, these roads are well suited for motorcycling.

Sometimes Coe will attend track days at Cadwell Park motor racing circuit where he can revel in the freedom to explore his bike's potential for speed. He also enjoys touring holidays to Scotland or southern Europe and riding with fellow medics in a motorcycle club for doctors called Quick Quacks.

If you think that motorcycles might be for you, consider the following:

- First, learn to drive a car well. Learners make mistakes. You are too vulnerable on a bike for that

- Assuming driving skills, keeping a $200 \mathrm{~kg}$ bike upright in a range of circumstances requires good balance and some strength. If this is a problem, stick to cars

- Bikers are so vulnerable that one significant error may be their last. If concentration is a problem, stick to cars

- Get professional tuition. It really helps

1 Department of Transport. Facts on motorcycle casualties. June 2015. https://assets.publishing.service.gov.uk/government/uploads/system/uploads/attachment_data/file/447673/motorcyclist-casualties-2013-data.pdf. 